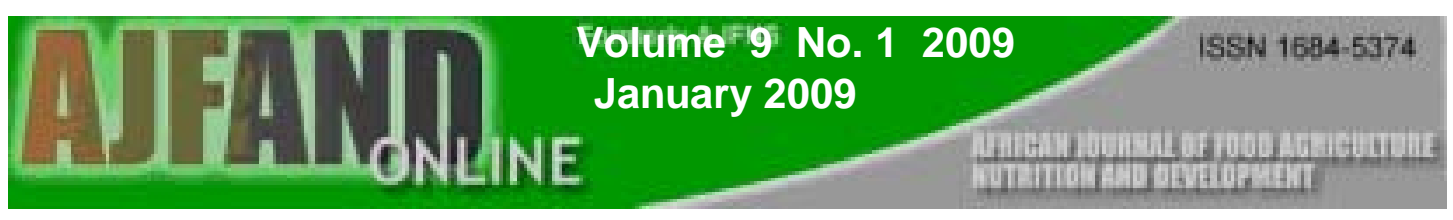

\title{
EFFECT OF SUB-CLINICAL MASTITIS ON MILK YIELD AND COMPOSITION OF DAIRY GOATS IN TANZANIA
}

\author{
Kifaro GC $^{1 *}$, Moshi NG ${ }^{1}$ and UM Minga ${ }^{2}$
}

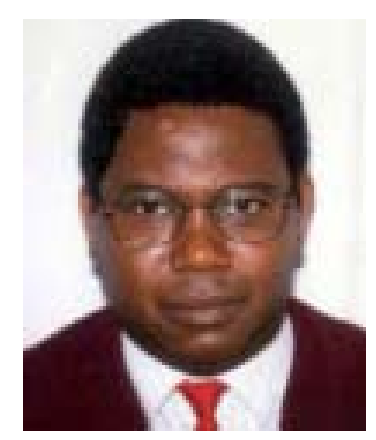

George Kifaro

*Corresponding author E-mail: kifaro@suanet.ac.tz

${ }^{1}$ Department of Animal Science and Production, Sokoine University Agriculture, P.O. Box 3004, MOROGORO, Tanzania.

${ }^{2}$ Open University of Tanzania, P.O. Box 23409, DAR-ES-SALAAM, Tanzania.

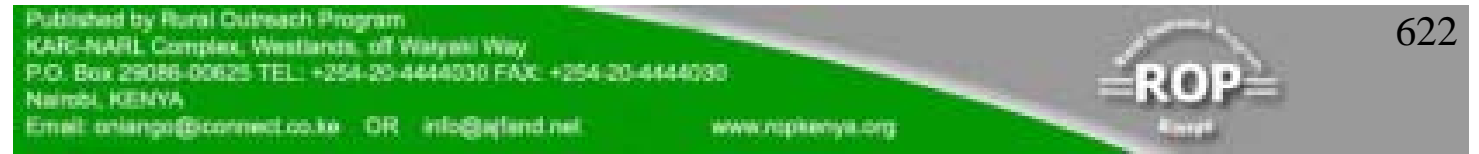




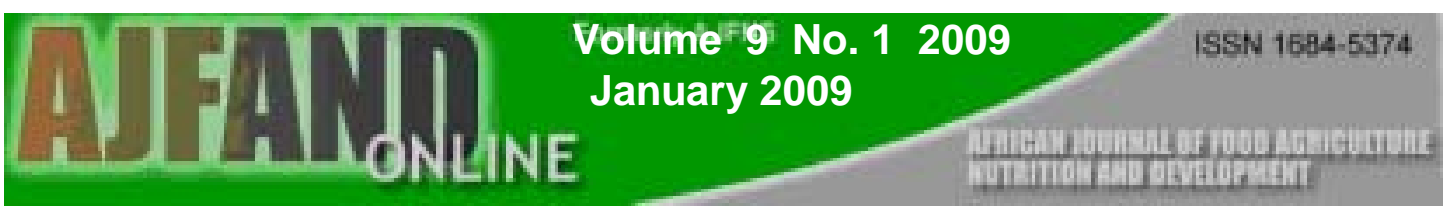

\section{ABSTRACT}

Production of dairy goats is on the increase in East African countries. As in cows, prevalence of mastitis in dairy goats appears to be high but studies on the influence of this disease on milk yield and composition are scarce. This study was, therefore, carried out to determine the effect of sub-clinical mastitis on milk yield and composition in dairy goats of Magadu dairy farm in Morogoro, Tanzania. Does were screened for mastitis using the California Mastitis Test (CMT), milk yield was recorded and $80 \mathrm{ml}$ samples collected for laboratory analyses. A total of 184 quarter milk yield samples were available for analyses. Milk samples were analysed for butterfat (BF) by the Gerber method, crude protein $(\mathrm{CP})$ by the Kjeldahl method, lactose by IDF Standard No. 28 method and chloride by titration using silver nitrate solution. Data were analysed using least squares analysis of variance based on General Linear models procedures. The fixed effects considered were CMT score, parity, stage of lactation, sampling occasion and quarter of the udder. Sub-clinical mastitis had a significant negative effect on quarter milk yield $(\mathrm{P}<0.001)$. Up to $29.4 \%$ milk reduction due to mastitis was recorded. Mastitis had a significant $(\mathrm{P}<0.05)$ effect on quarter crude protein, butter fat and chloride percentages but not on lactose content. There was a tendency for $\mathrm{CP}$ and chloride percentages to increase with increase in CMT scores. However, the mean chloride value obtained in this study of 0.244 was higher than expected. Further, mastitis significantly reduced BF content of milk from 6.32 in non-mastitic does to $4.91 \%$ among those with highest CMT score. The mean lactose percentage was 3.83. Subclinical mastitis had no significant influence on lactose content but there was a tendency for a decrease in this component with increase in severity of mastitis. It is recommended that further studies involving a bigger number of does with clinical mastitis be carried out to substantiate the present findings. Economic losses resulting from mastitis in goats also need to be assessed.

Key words: Mastitis, milk yield, composition, goats.

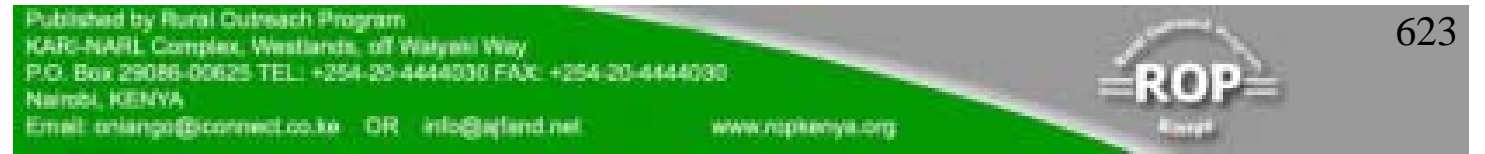




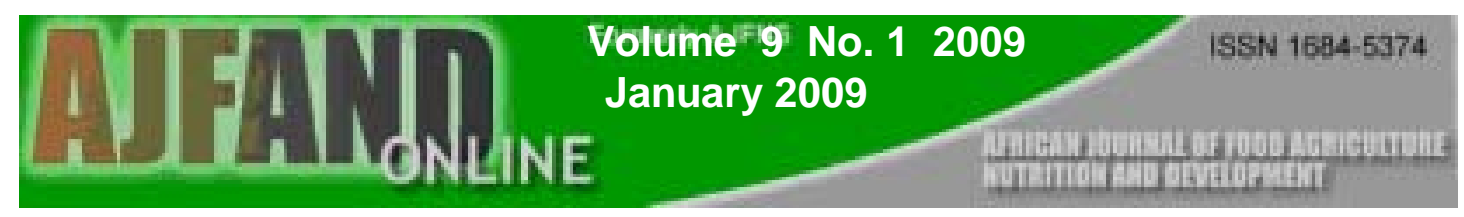

\section{INTRODUCTION}

Mastitis is universally recognised as one of the most costly disease in the dairy industry [1]. The major components of the economic losses caused by mastitis are: reduced milk yield, veterinary charges, increased labour costs, discarded milk and reduced longevity of milking goats [2]. High mortalities of kids born to goats with mastitis make the disease economically significant to the goat industry [3]. Milk yield in dairy animals can be reduced by as much as $25 \%$ and at times up to $100 \%$ [4]. The monetary loss the farmer gets as a result of this disease due to cows not producing optimally was estimated in Tanzania to be about Tsh. 52,800.00 (about US \$42) per cow per year, which was quite high [5].

Reports on the effect of bovine mastitis on milk composition show consistently lower lactose and higher chloride contents in quarters with mastitis than in those without mastitis $[5,6]$. Changes in fat content as a result of mastitis vary between sample populations mainly because the variation largely depends on the severity of mastitis and the magnitude of reduction in milk yield. The effect of mastitis on crude protein content of milk is not very clear under sub-clinical conditions although it is well known that at advanced stages, the trend is an increase in crude protein [7].

The majority of studies on the influence of mastitis on milk composition have been conducted in dairy cattle. In Tanzania there is a rapid increase of dairy goats especially among resource poor smallholder farmers. These goats contribute substantially towards sustainable supply of milk for children and women. Family incomes and nutrition have appreciably improved in the areas where dairy goats have been introduced [8]. However, an earlier study in two locations of Tanzania has clearly shown a high prevalence of subclinical mastitis in goats of over $70 \%$ [8]. Such a high incidence calls for the need to evaluate the effect of this disease on the yield and composition of milk. This is of paramount importance because there is limited information in goats on the effect of clinical and sub-clinical mastitis on milk yield and composition [4]. The objective of this study was therefore to establish the effect of sub-clinical mastitis on milk yield and composition in dairy goats.

\section{MATERIALS AND METHODS}

\section{Study area and animals}

This study was carried out at Magadu dairy farm. The farm belongs to the Department of Animal Science and Production of the Sokoine University of Agriculture (SUA), Morogoro, Tanzania. SUA is situated about $2.5 \mathrm{~km}$ south of Morogoro municipality at an altitude of $550 \mathrm{~m}$ above sea level and gets an average annual rainfall of approximately 880 $\mathrm{mm}$. For most parts of the year temperatures vary between $27^{0}$ and $31^{\circ} \mathrm{C}$.

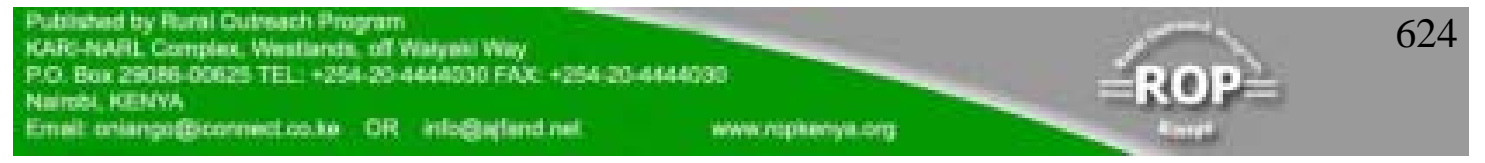




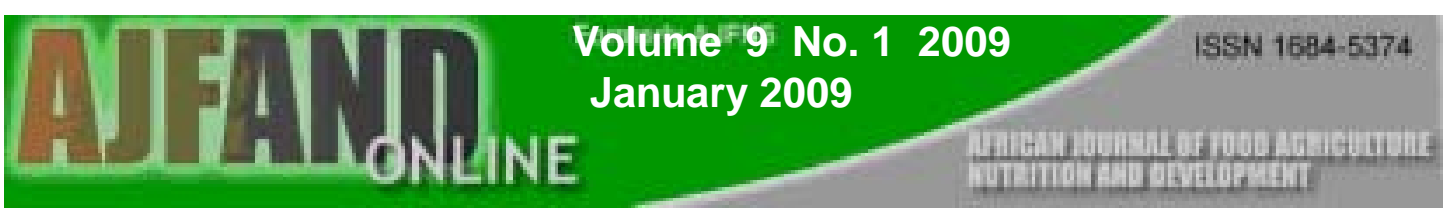

The goats at Magadu dairy farm were first crosses $\left(\mathrm{F}_{1}\right.$; Norwegian landrace $\mathrm{x}$ Local Tanzanian goats) with 50\% Norwegian blood.

\section{Milk yield and screening for mastitis}

Records on kidding date and parity for individual animals were taken. All lactating animals were screened and scored for mastitis using the California Mastitis Test (CMT) as described by Schalm and Noorlander [9]. Following screening, the CMT score of each udder quarter was included in the individual animal records. Goats were screened twice at two months interval.

All quarters screened for mastitis were milked to completion immediately following screening and in the next milking. The does were milked twice per day at around 6am and $5 \mathrm{pm}$ and the volume of milk obtained in each instance was measured in $\mathrm{ml}$.

\section{Collection of milk samples}

About $80 \mathrm{ml}$ of milk were collected from each of the screened quarter for milk composition analysis. Milk samples were preserved with potassium dichromate [10]. Before analyses composite samples were obtained by mixing quarter morning and evening samples in proportion to the milk yield at each milking.

\section{Analyses for milk constituents}

Milk samples from each quarter were analysed for crude protein $(\mathrm{CP})$, butterfat $(\mathrm{BF})$, lactose and chloride percentages. Total protein was determined by the standard Kjeldahl method for nitrogen analysis [11]. Nitrogen content was multiplied by 6.38 to obtain the $\mathrm{CP}$ percentage. The BF content was determined by the standard Gerber method [12]. The lactose content was determined according to the method described by IDF Standard No. 28 [13]. The chloride content of the milk samples was determined by titration using silver nitrate solution [14]. Koestler values usually increase in cases of mastitis, thus indicating infection. For normal milk this value is around 2.3. Koestler values (in percent) were computed by dividing the chloride content by lactose percentage for all CMT scores.

\section{Statistical analysis}

Records were analysed for effects of CMT score, parity, stage of lactation, quarter, sampling occasion (sampled twice) and milking time (for milk yield only). There were four (4) parities $\left(1^{\text {st }}, 2^{\text {nd }}, 3^{\text {rd }}\right.$ and $4^{\text {th }}$ and above $)$ and three stages of lactation $(1=\leq 5$ months of lactation, $2=>5$ and $<8$ months and $3=\geq 8$ months).

Analyses were performed according to the General Linear Models (GLM) procedures of SAS [15].

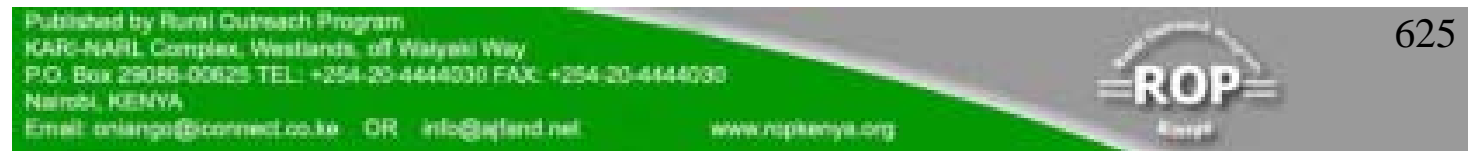




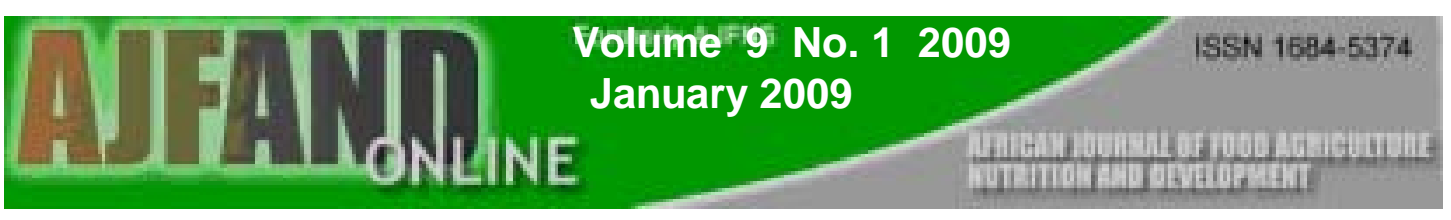

The model used was:

$\mathrm{Y}_{\mathrm{ijk} k m n o}=\mu \square \square+\mathrm{L}_{\mathrm{i}}+\mathrm{T}_{\mathrm{j}}+\mathrm{B}_{\mathrm{k}}+\mathrm{S}_{\mathrm{l}}+\mathrm{Q}_{\mathrm{m}}+\mathrm{A}_{\mathrm{n}}+\mathrm{b}\left(\mathrm{X}_{\mathrm{ijklmno}}-\mathrm{X}\right)+\mathrm{E}_{\mathrm{ijklmno}}$

Where:

$\mathrm{Y}_{\mathrm{ijklmno}}=$ dependent variable: milk yield, $\mathrm{CP}, \mathrm{BF}$, lactose, and

Chloride

$\mu=$ General mean

$L_{i}=$ Effect of the $i^{\text {th }}$ sampling occasion $(i=1,2)$

$\mathrm{T}_{\mathrm{j}}=$ Effect of sub-clinical mastitis (CMT score)

$(\mathrm{j}=0,1,2,3,4)$

$\mathrm{B}_{\mathrm{k}}=$ Effect of age in parturition number $(\mathrm{k}=1,2,3,4)$

$S_{1}=$ Effect of the $1^{\text {th }}$ stage of lactation $(1=1,2,3)$

$\mathrm{Q}_{\mathrm{m}}=$ Effect of the $\mathrm{m}^{\text {th }}$ quarter $(1=$ right, $2=$ left $)$

$\mathrm{A}_{\mathrm{n}}=$ Effect of the $\mathrm{n}^{\text {th }}$ milking time (1= morning, $2=$ evening $)$

$\mathrm{b}=$ Regression coefficient

$\mathrm{X}_{\mathrm{ijk} k m n}=$ Milk yield of the individual doe on the sampling day

$\mathrm{x}=$ Mean milk yield

$\mathrm{E}_{\mathrm{ijklmno}}=$ Random error term

The regression (covariate) was not included in the model when analysing milk yield data and effect of milking time was not fitted in the model when analysing milk components because morning and afternoon samples were mixed proportionately. 


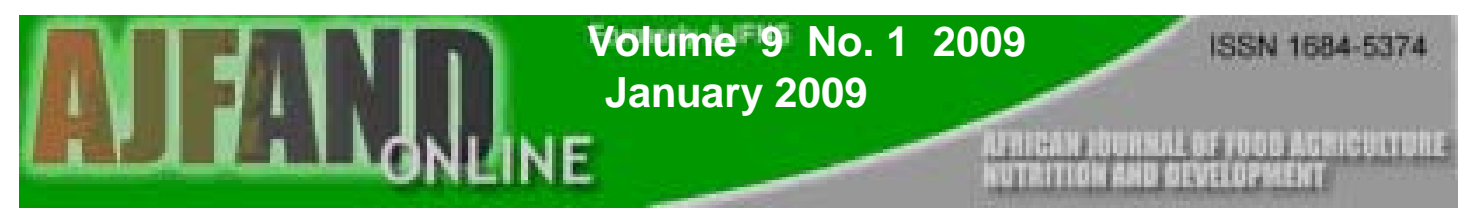

\section{RESULTS}

\section{Milk yield}

Least squares means of quarter milk yield per milking for the various factors are presented in Table 1. The overall mean quarter milk yield was $136.4 \pm 3.9 \mathrm{ml}$. Sub-clinical mastitis had a significant negative effect on quarter milk yield $(\mathrm{P}<0.001)$. There was an apparent decrease in milk yield with increase in CMT score. Effect of stage of lactation on milk yield was also significant $(\mathrm{P}<0.001)$. The effects of milking time and sampling occasion were highly significant $(\mathrm{P}<0.001)$ sources of variation. Morning milk yield was $40.4 \%$ higher than afternoon milk.

\section{Milk Composition}

The overall mean quarter $\mathrm{CP}$ percentage was $4.02 \pm 0.08$ (Table 1). Mastitis had a significant $(\mathrm{P}<0.01)$ effect on quarter $\mathrm{CP}$ percentage while parity and stage of lactation had no significant effect on levels of protein content. Quarters with highest CMT score had highest CP content.

The mean quarter BF percentage was $5.32 \pm 0.13$ (Table 2). There was a significant $(\mathrm{P}<0.01)$ reduction in $\mathrm{BF}$ content with increasing $\mathrm{CMT}$ score. Other factors that significantly influenced $\mathrm{BF}$ content were sampling occasion $(\mathrm{P}<0.001)$, stage of lactation $(\mathrm{P}<0.05)$ and milk yield $(\mathrm{P}<0.001)$. Butterfat increased from first $(4.30 \%)$ to second occasion $(6.35 \%)$ of sampling and also increased with stage of lactation from $4.59 \%$ in first stage to $6.16 \%$ in the last stage. Further, BF content in quarters with mastitis was lower compared to those with negative CMT score.

The overall mean quarter lactose percentage was $3.83 \pm 0.08$. The least square means of quarter lactose percent in relation to the various factors are shown in Table 2. None of the factors studied had a significant effect on quarter lactose percentage although lactose content tended to decrease with increase in CMT score.

Table 3 presents the least squares means for quarter chloride percentage for the various factors under study. The overall mean quarter chloride percentage was $0.244 \pm 0.003$. The effect of mastitis on quarter chloride percentage was highly significant $(\mathrm{P}<0.001)$ with a tendency for chloride content in milk to increase with increase in CMT score. Other significant effects on chloride percent included parity $(\mathrm{P}<0.001)$, sampling occasion $(\mathrm{P}<0.001)$ and udder quarter $(\mathrm{P}<0.05)$.

A very high Koestler value of $6.4 \%$ was obtained when it was computed using overall mean percentages of chloride and lactose. Koestler values for negative, trace, $+1,+2$ and +3 CMT scores were 5.3, 5.7, 6.7, 5.7 and 8.1, respectively showing an increase in values with severity of mastitis.

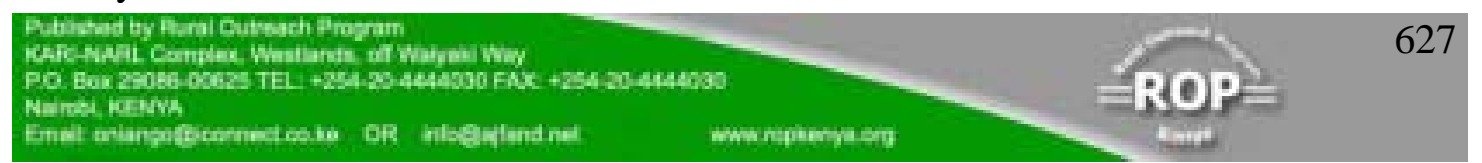




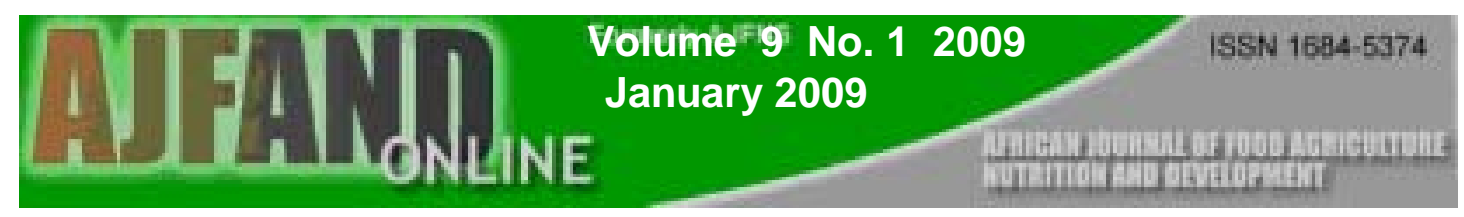

\section{DISCUSSION}

\section{Milk yield}

Sub-clinical mastitis had a significant negative effect on quarter milk yield. Such findings concur with previous reports in dairy goats [16] and in dairy cows [5,6], which showed significantly lower milk yield in mastitic quarters than in non-mastitic quarters. Mastitis is associated with tissue damage that brings about lowered milk yield or cessation of milk synthesis. The mechanism inhibiting the milk synthetic activity has been discussed in detail by a number of workers $[2,17]$.

\section{Milk composition}

The significant increase in CP content observed at Magadu has also been reported in severe bovine mastitis [7]. With severe inflammation, the combined effects of increased seepage of blood derived proteins and increased concentration of protein due to lowered milk yield may result in increased level of protein. In cases where CP content does not change, studies have shown that casein is dramatically reduced while the level of non-casein protein increases resulting in no change of CP [7]. Contrasting results have been reported by those working with bovine mastitis who found no significant change in $\mathrm{CP}$ with severity of mastitis $[5,6]$.

In this study mastitis significantly affected BF percentage but conflicting results have been reported on the effect of bovine mastitis on $\mathrm{BF}$ content. While some authors have demonstrated a reduction in $\mathrm{BF}$, others have shown $\mathrm{BF}$ percentage to increase with severity of mastitis $[5,7,18,19]$. Severity of mastitis seems to determine the magnitude of the effect. In mild cases of mastitis, milk yield is reduced without concomitant reduction in BF percentage. However, with severe inflammation both milk yield and BF concentration are significantly reduced.

There was a general tendency for lactose to decrease with increasing CMT score though this milk component was not significantly affected by sub-clinical mastitis. Studies with bovine mastitis have shown dramatic reduction in lactose content with severity of mastitis $[5,6]$. Goats are reported to be less susceptible to mastitis and that partly explains the lesser effect of sub-clinical mastitis on milk lactose content observed in this study [2]. It is further speculated that the level of mastitis as indicated by CMT score did not reach a stage of causing significant reduction in lactose percentage. Further studies with clinical mastitis are, therefore, needed in order to establish its influence on lactose content in goat milk.

The significant increase in chloride percent with severity of mastitis concurs with earlier reports $[5,6]$. The increase in chloride percent with mastitis is due to the increased permeability of blood vessels, which allows seepage of plasma into the udder. Even a small

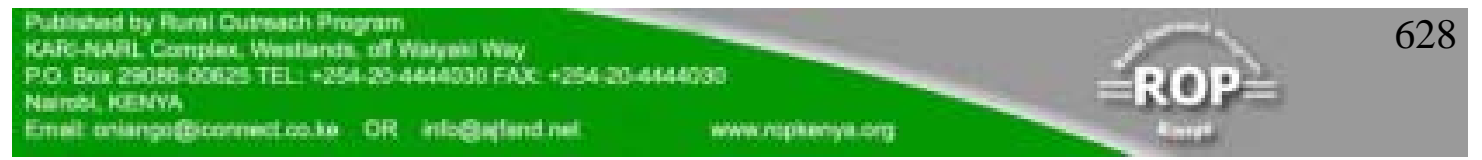




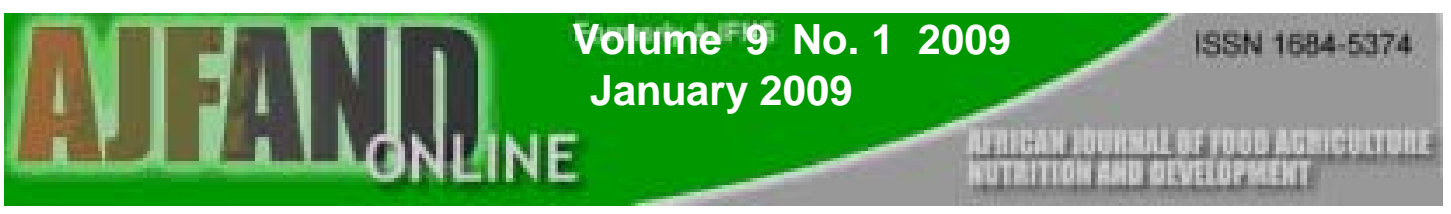

amount of blood derived exudates in milk is reported to result into an elevation in amount of chloride [20].

The overall percent chloride of $0.244 \%$ was higher than results observed in the literature where chloride percentages of a range of 0.107 to $0.193 \%$ have been reported [21, 22]. The high mean would suggest existence of mastitis in the flock that was studied as was reported earlier [8].

In mastitis cases, as lactose decreases it is compensated for by increase in chlorides in order to maintain osmotic pressure. However, the Koestler values obtained in this study are much higher compared to that shown by other reviews of about $2.3 \%$ [23]. The main reason for high Koestler values here is that the chloride content in milk was almost double the expected values as discussed above.

\section{CONCLUSION AND RECOMMENDATION}

\section{Conclusion}

1. It has been shown that sub-clinical mastitis can reduce milk yield up to $29.4 \%$.

2. There was a tendency for $\mathrm{CP}$ and chloride percentages to increase with severity of mastitis, however, the chloride values obtained in this study were higher than expected.

3. Mastitis significantly reduced BF content of milk. Further, sub-clinical mastitis had no significant influence on lactose content though there was a tendency for this component to decrease with increase in CMT score.

\section{Recommendation}

It is recommended that further studies involving a larger sample of does and those with clinical mastitis be conducted to substantiate the present findings and economic losses resulting from mastitis in goats be assessed.

\section{ACKNOWLEDGEMENT}

Financial support from the Norwegian Agency for International Development (NORAD) is gratefully acknowledged.

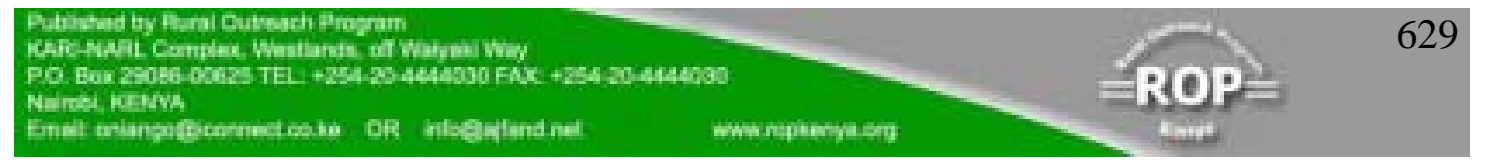




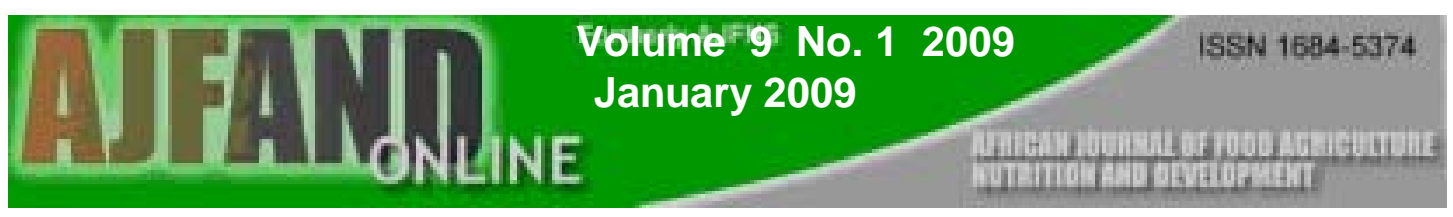

Table 1: $\quad$ Least squares means $(\mathrm{LSM} \pm \mathrm{SE})$ of quarter milk yield $(\mathrm{ml})$ and crude protein content $(\%)$ for various factors

\begin{tabular}{|c|c|c|c|c|}
\hline \multicolumn{5}{|c|}{ Variable } \\
\hline \multirow[t]{2}{*}{ Factor } & \multicolumn{2}{|c|}{ Quarter milk yield } & \multicolumn{2}{|c|}{ Crude protein } \\
\hline & $\mathbf{n}$ & LSM & $\mathbf{n}$ & LSM \\
\hline Overall & 184 & $136.4 \pm 3.9$ & 81 & $4.02 \pm 0.08$ \\
\hline CMT -ve & 48 & $146.4 \pm 8.7^{\mathrm{a}}$ & 21 & $4.11 \pm 0.21^{\mathrm{ab}}$ \\
\hline $\mathrm{T}$ & 38 & $175.9 \pm 9.3^{\mathrm{b}}$ & 18 & $3.78 \pm 0.21^{\mathrm{a}}$ \\
\hline+1 & 40 & $146.3 \pm 9.1^{\mathrm{a}}$ & 17 & $3.61 \pm 0.20^{\mathrm{a}}$ \\
\hline+2 & 34 & $127.3 \pm 9.1^{\mathrm{ac}}$ & 14 & $3.70 \pm 0.21^{\mathrm{a}}$ \\
\hline+3 & 24 & $103.4 \pm 9.4^{\mathrm{c}}$ & 11 & $4.52 \pm 0.25^{\mathrm{b}}$ \\
\hline Parity 1 & 64 & $143.1 \pm 7.9$ & 29 & $3.78 \pm 0.18$ \\
\hline 2 & 38 & $151.3 \pm 9.4$ & 19 & $3.73 \pm 0.20$ \\
\hline 3 & 34 & $132.5 \pm 10.6$ & 16 & $4.06 \pm 0.21$ \\
\hline 4 & 48 & $132.6 \pm 7.8$ & 17 & $4.21 \pm 0.19$ \\
\hline Stage of lact. 1 & 34 & $129.4 \pm 11.0^{\mathrm{ab}}$ & 13 & $3.87 \pm 0.25$ \\
\hline 2 & 94 & $133.5 \pm 6.1^{\mathrm{a}}$ & 27 & $4.01 \pm 0.12$ \\
\hline 3 & 56 & $156.8 \pm 8.3^{\mathrm{b}}$ & 20 & $3.95 \pm 0.22$ \\
\hline Sampling phase 1 & 108 & $101.5 \pm 6.7^{\mathrm{a}}$ & 41 & $4.28 \pm 0.16^{\mathrm{a}}$ \\
\hline 2 & 76 & $178.2 \pm 6.8^{\mathrm{b}}$ & 40 & $3.61 \pm 0.20^{\mathrm{b}}$ \\
\hline Quarter 1 & 92 & $138.4 \pm 6.2$ & 41 & $3.89 \pm 0.13$ \\
\hline 2 & 92 & $141.3 \pm 6.2$ & 40 & $4.00 \pm 0.13$ \\
\hline
\end{tabular}

$\mathrm{CMT}=$ California mastitis test,$-\mathrm{ve}=$ Negative CMT score, $\mathrm{T}=$ Trace CMT score, LSM with common superscripts within column within factor were not significantly different at $\mathrm{P}>0.05$.

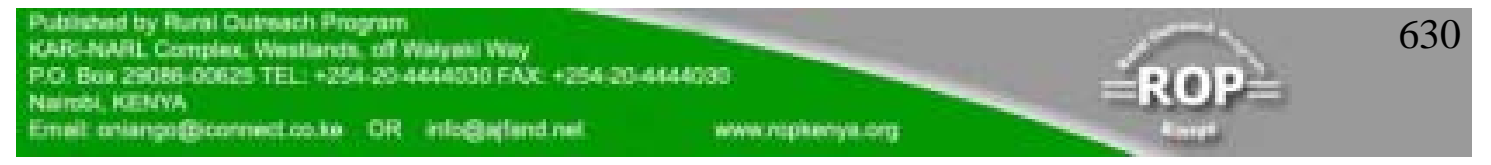




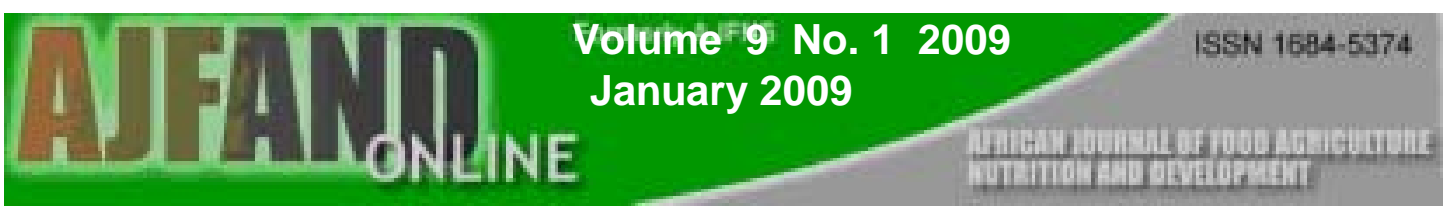

Table 2: Least squares means $(\mathrm{LSM} \pm \mathrm{SE})$ of butterfat and lactose for various factors

\begin{tabular}{|c|c|c|c|c|}
\hline \multicolumn{5}{|c|}{ Variable } \\
\hline \multirow[t]{2}{*}{ Factor } & \multicolumn{2}{|c|}{ Butterfat } & \multicolumn{2}{|c|}{ Lactose } \\
\hline & $\mathbf{n}$ & LSM & $\mathbf{n}$ & LSM \\
\hline Overall & 87 & $5.32 \pm 0.13$ & 92 & $3.83 \pm 0.08$ \\
\hline CMT-ve & 24 & $6.32 \pm 0.30^{\mathrm{a}}$ & 24 & $4.14 \pm 0.18$ \\
\hline $\mathrm{T}$ & 20 & $5.93 \pm 0.30^{\mathrm{a}}$ & 20 & $4.08 \pm 0.19$ \\
\hline+1 & 18 & $4.58 \pm 0.31^{\mathrm{b}}$ & 19 & $3.62 \pm 0.19$ \\
\hline+2 & 17 & $4.86 \pm 0.31^{\mathrm{b}}$ & 17 & $4.17 \pm 0.19$ \\
\hline+3 & 8 & $4.91 \pm 0.45^{\mathrm{b}}$ & 12 & $3.51 \pm 0.24$ \\
\hline Parity 1 & 31 & $5.27 \pm 0.27$ & 32 & $3.78 \pm 0.16$ \\
\hline 2 & 19 & $5.43 \pm 0.31$ & 20 & $4.13 \pm 0.19$ \\
\hline 3 & 19 & $5.22 \pm 0.32$ & 19 & $3.81 \pm 0.20$ \\
\hline 4 & 18 & $5.38 \pm 0.29$ & 21 & $3.91 \pm 0.17$ \\
\hline Stage of lact. 1 & 17 & $4.59 \pm 0.38^{\mathrm{a}}$ & 17 & $4.09 \pm 0.23$ \\
\hline 2 & 49 & $5.22 \pm 0.19^{\mathrm{a}}$ & 52 & $3.69 \pm 0.11$ \\
\hline 3 & 21 & $6.16 \pm 0.35^{\mathrm{b}}$ & 23 & $3.93 \pm 0.20$ \\
\hline Sampling phase 1 & 49 & $4.30 \pm 0.25^{\mathrm{a}}$ & 54 & $3.78 \pm 0.15$ \\
\hline 2 & 38 & $6.35 \pm 0.27^{\mathrm{b}}$ & 38 & $4.03 \pm 0.16$ \\
\hline Quarter 1 & 43 & $5.07 \pm 0.21$ & 47 & $3.88 \pm 0.12$ \\
\hline 2 & 44 & $5.60 \pm 0.20$ & 45 & $3.93 \pm 0.12$ \\
\hline
\end{tabular}

$\mathrm{CMT}=$ California mastitis test,$-\mathrm{ve}=$ Negative CMT score, $\mathrm{T}=$ Trace CMT score, LSM with common superscripts within column within factor were not significantly different at $\mathrm{P}>0.05$.

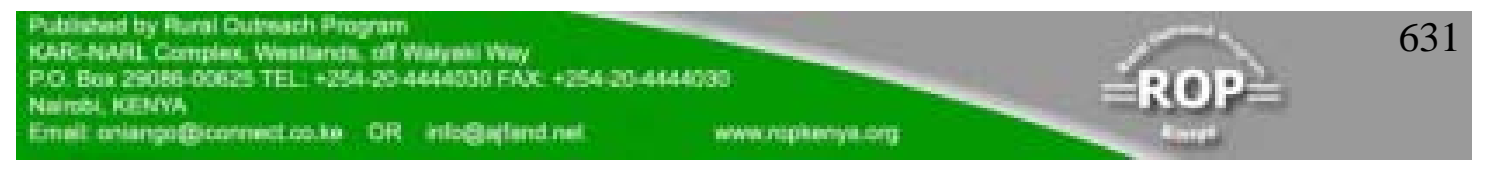




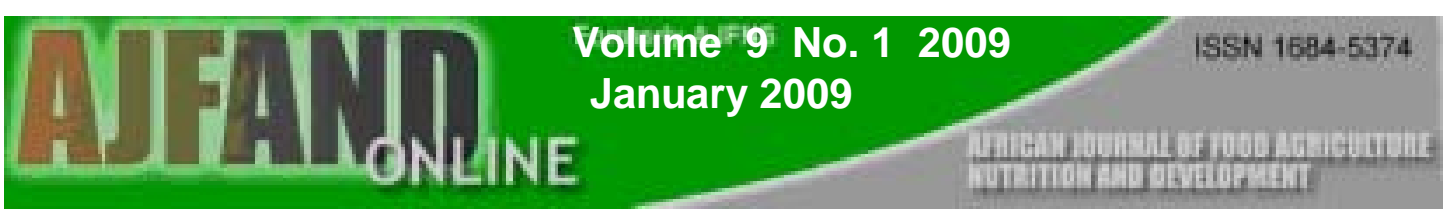

Table 3: $\quad$ Least squares means $(\mathrm{LSM} \pm \mathrm{SE})$ of quarter chloride percentage for the various factors

\begin{tabular}{|c|c|c|}
\hline Factor & $\mathrm{N}$ & LSM \\
\hline Overall & 90 & $0.244 \pm 0.003$ \\
\hline CMT -ve & 24 & $0.220 \pm 0.007^{\mathrm{a}}$ \\
\hline $\mathrm{T}$ & 20 & $0.233 \pm 0.007^{\mathrm{ab}}$ \\
\hline+1 & 18 & $0.244 \pm 0.007^{\mathrm{b}}$ \\
\hline+2 & 17 & $0.238 \pm 0.007^{\mathrm{ab}}$ \\
\hline+3 & 11 & $0.283 \pm 0.009^{\mathrm{c}}$ \\
\hline Parity 1 & 32 & $0.239 \pm 0.006^{\mathrm{a}}$ \\
\hline 2 & 19 & $0.221 \pm 0.007^{\mathrm{b}}$ \\
\hline 3 & 19 & $0.249 \pm 0.007^{\mathrm{ac}}$ \\
\hline 4 & 20 & $0.265 \pm 0.006^{c}$ \\
\hline Stage of lact. 1 & 17 & $0.248 \pm 0.008$ \\
\hline 2 & 51 & $0.244 \pm 0.004$ \\
\hline 3 & 22 & $0.239 \pm 0.008$ \\
\hline Sampling phase 1 & 52 & $0.276 \pm 0.005^{\mathrm{a}}$ \\
\hline 2 & 38 & $0.212 \pm 0.006^{\mathrm{b}}$ \\
\hline Quarter 1 & 46 & $0.252 \pm 0.005^{\mathrm{a}}$ \\
\hline 2 & 44 & $0.236 \pm 0.005^{\mathrm{b}}$ \\
\hline
\end{tabular}

$\mathrm{CMT}=$ California mastitis test,$-\mathrm{ve}=$ Negative CMT score

$\mathrm{T}=$ Trace CMT score, LSM with common superscripts within column within factor were not significantly different at $\mathrm{P}>0.05$.

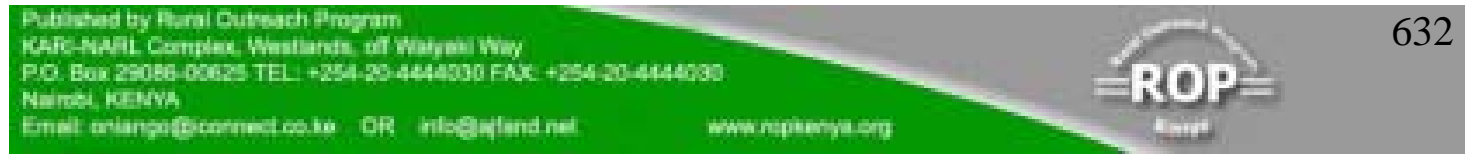




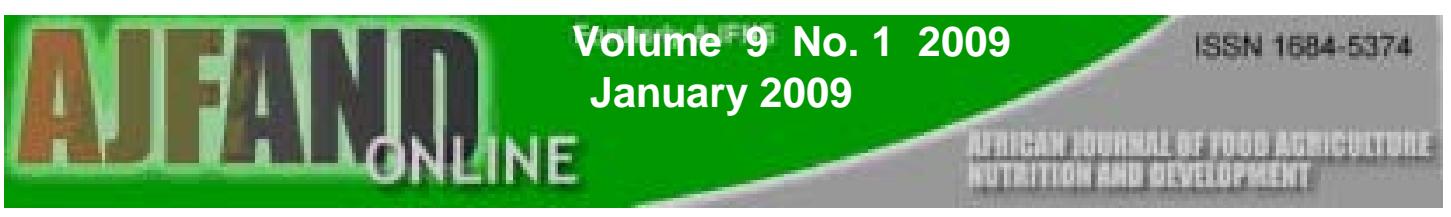

\section{REFERENCES}

1. Alrawi AA, Pollak EJ and RC Laben Genetic analysis of California mastitis test records. I. Coded tests. J. Dairy Sci. 1979; 62: 1115-1124.

2. Blood DC and OM Radostits Veterinary Medicine: A textbook of diseases of cattle, sheep, pigs, goats and horses. Bailliere Tindall, Philadelphia. 1989:501-559.

3. Addo PB, Chimene CN and FIA Eid Incidence and importance of Chronic mastitis in Nigeria goats. Bull. Anim. Hlth and Prod. Africa 1980; 28: 225-231.

4. Peacock C Improving Goat Production in the Tropics. Manual for development workers. Oxfam U.K and Ireland in association with FARM - Africa. 1996: 200202.

5. Mosha CJS Effects of Mastitis on yield and composition of milk in selected dairy farms in Morogoro Municipality. Unpublished M.Sc.Dissertation, Sokoine University of Agriculture (SUA), 1993.

6. Nangwala SW Effect of mastitis on quarter milk yield response to improved feeding. Unpublished M. Sc. Dissertation, Sokoine University of Agriculture, 1996.

7. Ashworth US, Forster TL and LO Luedecke Relationship between California mastitis test reaction and composition of milk from opposite quarters. J. Dairy Sci. 1967; 50:1078-1082.

8. Moshi NG, Kifaro GC and UM Minga Prevalence of mastitis in dairy goats on some selected farms in Morogoro and Arusha, Tanzania J. Agric. Sci. 1998;1(2): $173-180$.

9. Schalm OW and DO Noorlander Experiments and observations leading to the development of the California Mastitis Test. J. American Vet. Medical Assoc. 1957; 130: 199-204.

10. Weaver HC and M Kroger Protein, casein and non-casein protein percentages in milk with high somatic cell counts. J.Dairy Sci. 1977; 60: 878-881.

11. AOAC. Association of Official Analytical Chemists. Official Methods of Analysis $15^{\text {th }}$ Edition Arlington Virginia, USA, 1990. 


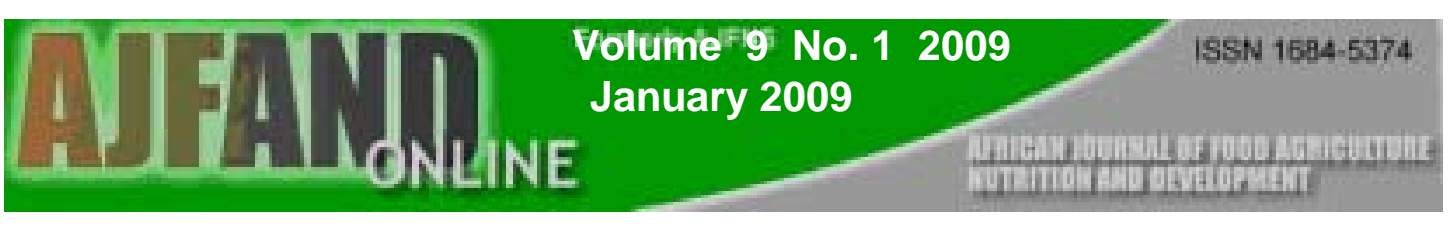

12. Van den Berg JCT Dairy Technology in the tropics and sub-tropics. Centre for Agricultural Publishing and Documentation (Pudoc) Wageningen, 1988.

13. IDF. (International Dairy Federation) Determination of the lactose content of milk. IDF International Standards No.28,1974.

14. Marth EH Standard Methods for the Examination of Dairy Products. Donely and sons Inc. Crawfordsville, USA, 1978.

15. SAS. The GLM procedure. SAS/STAT User's guide. 6.03 edition, SAS Institute Incorporation. Cary, NC, 2002.

16. Dulin A, Paape M, Schultze W and B Weinland Effect of parity, stage of lactation and intramammary infection on concentration of somatic cells and cytoplasmic particles in goat's milk. J. Dairy Sci. 1983; 66: 2426-2433.

17. Jubb KVF and PC Kennedy: Pathology of domestic animals. Vol. 1. Academic Press, New York, 1970:552 - 572.

18. Janzen JJ Economic losses resulting from mastitis. J. Dairy Sci. 1970; 53(8): 1151-1161.

19. Philpot WN Influence of sub-clinical mastitis on milk production and milk composition. J. Dairy Sci. 1967; 50: 978-985.

20. Coles EN Veterinary Clinical Pathology. W.B. Saunders Company, 1986:359-367.

21. Parkash $\mathbf{S}$ and $\mathbf{R}$ Jenness The composition and characteristics of goat milk: A review. Dairy Sci. Abstr. 1968; 20: 67-87.

22. Payne WJA An Introduction to Animal Husbandry in the Tropics. Longman John Wiley and Son, Inc., New York, 1990.

23. Kurwijila RL Genetic and environmental aspects of milk production under tropical environment. Compendium for M.Sc. Course in Dairy production and management. Mimeograph, Morogoro, 1991.

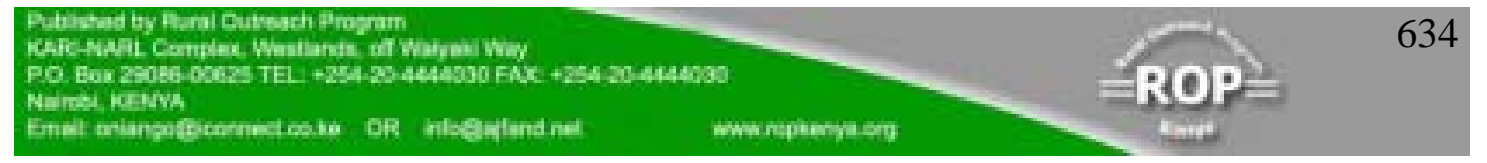

